\title{
Incorporation of Ethics and Societal Impact Issues into Senior Capstone De- sign Courses: Results of a National Survey
}

\author{
Dr. Angela R. Bielefeldt, University of Colorado, Boulder
}

Angela Bielefeldt is a professor at the University of Colorado Boulder in the Department of Civil, Environmental, and Architectural Engineering (CEAE). She has served as the the ABET assessment coordinator for her department since 2008. Professor Bielefeldt is the faculty director of the Sustainable By Design Residential Academic Program, a living-learning community where interdisciplinary students learn about and practice sustainability. Bielefeldt is also a licensed P.E. Professor Bielefeldt's research interests in engineering education include service-learning, sustainable engineering, social responsibility, ethics, and diversity.

\section{Ms. Madeline Polmear, University of Colorado, Boulder}

Madeline Polmear is a PhD student and research assistant in the Department of Civil, Environmental, and Architectural Engineering in the College of Engineering and Applied Science at the University of Colorado, Boulder. She is interested in studying how macroethics are taught to engineering and computing students.

\section{Dr. Daniel Knight, University of Colorado, Boulder}

Daniel W. Knight is the Program Assessment and Research Associate at Design Center (DC) Colorado in CU's Department of Mechanical Engineering at the College of Engineering and Applied Science. He holds a B.A. in psychology from Louisiana State University, an M.S. degree in industrial/organizational psychology and a Ph.D. degree in education, both from the University of Tennessee. Dr. Knight's research interests are in the areas of retention, program evaluation and teamwork practices in engineering education. His current duties include assessment, team development and education research for DC Colorado's hands-on initiatives.

\section{Dr. Nathan E. Canney, Seattle University}

Dr. Canney teaches civil engineering at Seattle University. His research focuses on engineering education, specifically the development of social responsibility in engineering students. Other areas of interest include ethics, service learning, and sustainability education. Dr. Canney received bachelors degrees in Civil Engineering and Mathematics from Seattle University, a masters in Civil Engineering from Stanford University with an emphasis on structural engineering, and a $\mathrm{PhD}$ in Civil Engineering from the University of Colorado Boulder.

\section{Dr. Christopher W. Swan, Tufts University}

Chris Swan is an associate professor in the Civil and Environmental Engineering department at Tufts University. He has additional appointments in the Department of Education, Jonathan M. Tisch College of Civic Life and Center for Engineering Education and Outreach at Tufts. His current engineering education research interests focus on learning through service-based projects and using an entrepreneurial mindset to further engineering education innovations. He also researches the development of reuse strategies for waste materials. 


\title{
Incorporation of Ethics and Societal Impact Issues into Senior Capstone Design Courses: Results of a National Survey
}

\begin{abstract}
This paper provides an overview of the ways that ethics and societal impacts (ESI) are taught and assessed in senior capstone design courses by engineering faculty. A national survey was conducted in spring 2016 that asked engineering and computing faculty to report the types of courses where they incorporated ESI. Among the 1216 respondents who incorporated these topics into one or more courses, $486(40 \%)$ indicated that they taught these topics in capstone design across a range of disciplines. The ESI topics taught by over half of the capstone design instructors included: professional practice issues, safety, engineering decisions in the face of uncertainty, and engineering codes of ethics. On average, individuals $(n=212)$ reported using five different methods to teach students about ESI in their capstone courses, most commonly: engineering design projects $(70 \%)$, in-class discussions $(58 \%)$, case studies $(58 \%)$, examples of professional scenarios (57\%), and lectures (55\%). This range of methods appears to involve the cognitive, affective, social, and psychomotor domains of learning, which has been proposed as providing an effective way to improve ethical reasoning. For assessment of ESI learning, an average of two methods were used per course with a maximum of 8 methods reported; $10 \%$ did not assess ESI knowledge. The most commonly used assessment methods were: group-based written assignments (47\%), individual reflections (33\%), and individual homework assignments graded with a rubric $(31 \%)$. Instructor satisfaction with the ability to assess the outcomes of societal context and ethics instruction was weakly correlated with the number of assessment methods used (correl. coeff. 0.25). Among all survey respondents $62 \%$ believed that undergraduate students in their program learned about ESI via capstone design, the most commonly identified course type. The results of this study indicate that ethical and societal impact issues can be readily incorporated into capstone design courses in any discipline, and provides examples of effective teaching and assessment methods.
\end{abstract}

\section{Introduction}

It is vitally important that all engineering and computing professionals consider the ethical and societal implications of their work. ${ }^{1}$ This includes following the codes of ethics that set expectations for the profession, therefore placing human health, safety, and welfare above all other factors. ${ }^{2-8}$ Increasingly, engineering and computing professionals are being asked to consider the broader societal, environmental, and economic implications of their work. ${ }^{9-10}$ This recognition has been incorporated into the educational requirements for engineering and computing students; for example, ABET EAC Criterion 3 outcome $(\mathrm{h})^{11}$ and ABET CAC Criterion 3 outcome $\mathrm{G}^{12}$. These broader impacts can be considered macroethical issues, where the profession itself has responsibilities. ${ }^{13}$ The proposed ABET EAC Criterion 3 Outcome $5^{11}$ seems to acknowledge this more holistic view of ethics: "An ability to recognize ethical and professional responsibilities in engineering situations and make informed judgments, which must consider the impact of engineering solutions in global, economic, environmental, and societal contexts." (pg. 26). 
There are a number of different curricular models for educating engineering and computing students about ethical issues. Given the broad nature of the accreditation criteria, it has been argued that at its most basic level, "an understanding of professional and ethical responsibility" might simply be achieved solely through seminars or a lecture. ${ }^{14}$ However, most programs aim higher, and include education on ethics within a number of contexts. The most comprehensive are programs that include an "ethics across the curriculum" approach. ${ }^{15-17}$ Thus ethics is infused into a number of required courses, typically side-by-side with core technical material. Some programs have an entire course dedicated to ethics, ranging from one to three credits (e.g. University of Missouri St. Louis, University of Illinois Urbana Champaign, Texas A\&M University, Georgia Institute of Technology). ${ }^{18-25}$ These may be taught by engineering and/or philosophy faculty. Other common places to teach ethics include first year introductory courses (e.g. Cornell University, Penn State University) ${ }^{26-28}$ and capstone design (e.g. Kettering University) $)^{22,29-30}$.

One might expect that capstone design courses would be an ideal setting for ethics education. Vanasupa's Four Domain Development Diagram (4DDD) ${ }^{31}$ proposed that ethical reasoning could be enhanced as students moved through cognitive, affective, psychomotor, and social domains of learning. Capstone design often incorporates all of these learning environments through hands-on team projects. Further, the 4DDD model proposes that internal motivation drives student learning. The context of a senior design project might provide interest and/or value related to ethical issues. Autonomy-related elements may also be present, since students often have some choice related to their project and/or how they execute their project. Vanasupa et al. ${ }^{31}$ describe a "potential strategic path to increase moral and ethical development" (p. 73) for students, where systems thinking originating in the cognitive domain led to understanding the broader context; that understanding fed into the students' motivational cycle for learning leading to increased engagement and active learning as well as moral and ethical development. They position moral and ethical development at the intersection of the social and affective domains. Thus, the team-based and immersive context of many capstone design projects and courses may serve as ideal settings for students' ethical development.

There are numerous reports in the literature of the incorporation of ethical and societal impact issues into capstone design courses. In the 2015 Capstone Design Survey, Howe et al. ${ }^{32}$ reported the findings from 522 respondents representing 464 departments at 256 institutions. Engineering ethics was a topic covered in lectures, individual assignments, or as part of the team project in $69 \%, 30 \%$, and $45 \%$ of the courses, respectively; only $12 \%$ indicted that engineering ethics was not covered in their capstone design course. Sustainability was a topic covered in lectures, individual assignments, and team projects in 44\%, 13\%, and 53\% of the courses, respectively; it was not covered in $27 \%$ of the courses. In a large study on ethics with responses from 1,692 upper division students attending 19 different institutions, 29\% indicated that they learned about ethics in their senior design / capstone course and $11 \%$ indicated that senior design was the setting they considered the most influential if they were facing an engineering ethical dilemma. ${ }^{33}$ Students reported an average of 1.2 different pedagogies used to teach ethics in capstone design, most commonly a presentation by a professor. ${ }^{33}$ Similarly, a survey of Chemical Engineering capstone design courses, $54 \%$ included ethics, $45 \%$ waste minimization, and $23 \%$ sustainability/life cycle analysis; another $64 \%$ or more included various safety topics (based on 69 responses representing 64 institutions). ${ }^{34}$ In addition, 52\% indicated that the chemical 
engineering capstone design course was used to assess ABET outcome F (ethics), with 22\% indicating "extensive" assessment of this outcome. For ABET outcome H (societal impacts), $46 \%$ used the chemical engineering capstone design course to assess the outcome, with $17 \%$ citing extensive assessment of this outcome. In contrast, a 2005 study with results from 50 computer science departments found that about $10 \%$ (5 of 50 programs) appeared to integrate ethics content into senior capstone projects ${ }^{35}$; it is unclear if this was interpreted to mean only microethical issues or also broader societal impacts. Now, ten years after this study was published, it is uncertain if there is more integration of ethical issues into computer science capstone courses more similar to the level observed in engineering.

Capstone design courses that include service-learning projects, human centered design, and/or humanitarian engineering often include a variety of clear and important ethical issues. The mechanical engineering capstone course at the University of South Florida was described as including reading and discussion of two engineering ethics case studies, as well as many service projects focused on assistive technologies in partnership with the center for Rehabilitation Engineering and Technology. ${ }^{36}$ At Gonzaga the two-semester computer science capstone design course has integrated ethics via a set of modules that focus on professional ethics, societal impacts, and legal issues. ${ }^{37}$ The course includes software projects for external clients, some of which include a clear human and environmental-centered focus (examples: helping people with Parkinson's Disease, sleeping disorders, fitness needs; medical waste, energy and water use on campus, etc.).

While the literature reports ethics education in a number of different capstone design courses, it is mostly descriptive, and questions remain about the most effective methods and disciplinary differences.

\section{Research Questions}

The following research questions were explored in this study:

RQ1. What types of ethics-related topics are included in capstone design courses? Does this vary between disciplines?

RQ2. What methods are used in capstone design courses to teach ethics and societal impact topics? Do these methods appear to vary among disciplines or topics?

RQ3. What methods are used in capstone design courses to assess the outcomes of ethics education?

RQ4. Do engineering faculty believe that undergraduate students learn about ethical issues in capstone design courses? Does this vary by disciplines?

\section{Methods}

All research was conducted in accordance with a protocol approved by the Institutional Review Board for Human Subjects Research. A survey was developed to solicit information from faculty about how they teach and asses ethics in both courses and co-curricular settings. ${ }^{38-40}$ Briefly, three pilot surveys were developed based on a thorough literature review. These surveys were tested with faculty at three institutions, followed by a series of interviews on the surveys. From 
this information two final surveys resulted. One survey started with questions on teaching ethical issues in courses (the "curricular" survey) and the other survey started with questions on ethics topics in co-curricular settings (the "co-curricular" survey). The course-based questions were identical in both versions of the survey. The questions relevant to the current study are shown in Table 1. The survey concluded with demographic questions, including: engineering disciplines where you teach societal context and/or ethics (check all that apply), institution (please fill in), the highest degree's awarded at your institution, institution type (public/private), your academic rank, do you hold additional roles at your institution (check all that apply; dean, department chair or head, etc.), gender, race, ethnicity, do you hold a professional engineering license (P.E. or similar). Respondents could choose to skip any questions.

Table 1. Survey questions pertaining to this research

\begin{tabular}{|c|c|}
\hline Survey Question / Statement & Response Options \\
\hline $\begin{array}{l}\text { 1. Do you teach engineering and/or computing students about any of the following } \\
\text { topics in any of your undergraduate and/or graduate courses? (check all that apply) }\end{array}$ & $\begin{array}{l}18 \text { topic options, Other } \\
\text { (identify), and No topics } \\
\text { related to... }\end{array}$ \\
\hline $\begin{array}{l}\text { 2. In what type of courses do you teach students about the societal impacts of } \\
\text { engineering and/or ethics (check all that apply) }\end{array}$ & $\begin{array}{l}9 \text { options and Other } \\
\text { (identify) }\end{array}$ \\
\hline \multicolumn{2}{|c|}{$\begin{array}{l}\text { Think about the ONE course in which you believe you most effectively teach engineering } \\
\text { and/or computing students about the societal impacts of technology and/or ethics. [You may } \\
\text { also choose to describe a second course later in the survey.] }\end{array}$} \\
\hline 3. The title of this course is: & Open response box \\
\hline 4. This course would best be characterized as (check all that apply) & $\begin{array}{l}4 \text { options: required } \\
\text { undergraduate, elective } \\
\text { ugrad, req'd graduate, } \\
\text { elective graduate }\end{array}$ \\
\hline $\begin{array}{l}\text { \{if above was a course for undergraduate students, display question } 4 b \text { \} } \\
4 \mathrm{~b} \text {. The course type is also (select single most descriptive): }\end{array}$ & $\begin{array}{l}8 \text { options and Other } \\
\text { (explain) }\end{array}$ \\
\hline $\begin{array}{l}\text { 5. What methods do you use in this course to teach students about societal issues? } \\
\text { (check all that apply) }\end{array}$ & $\begin{array}{l}15 \text { options and Other(s) [fill } \\
\text { in] }\end{array}$ \\
\hline $\begin{array}{l}\text { 6. How do you assess students' knowledge of the societal impacts of technology } \\
\text { and/or ethics in this course? (check all that apply) }\end{array}$ & $\begin{array}{l}8 \text { options, Other (describe), } \\
\text { and Do not assess these } \\
\text { learning outcomes }\end{array}$ \\
\hline $\begin{array}{l}\text { 7. In general, how satisfied are you with your ability to assess the outcomes of } \\
\text { societal context and/or ethics instruction in this course? }\end{array}$ & $\begin{array}{l}1 \text { to } 7 \text { scale (very } \\
\text { dissatisfied - very satisfied) }\end{array}$ \\
\hline $\begin{array}{l}\text { 8. Would you like to tell us about a second course where you teach students about } \\
\text { societal and/or ethical issues related to engineering/computing? }\end{array}$ & $\begin{array}{l}\text { Yes/No } \\
\{\text { if yes, repeat Q3-7\} }\end{array}$ \\
\hline $\begin{array}{l}\text { 9. Where do you think undergraduate students in your program learn about the } \\
\text { societal impacts of technology and/or ethical issues? [check all that apply] }\end{array}$ & $\begin{array}{l}8 \text { course options, } 2 \text { co- } \\
\text { curricular options, Other } \\
\text { (please explain), and Unsure }\end{array}$ \\
\hline
\end{tabular}

Input from capstone course instructors was not directly solicited, but rather a broad national survey of ethics instruction was conducted from which the capstone design results were extracted. The survey invitations were emailed in February to May 2016. Invitations to the curricular survey were sent to email lists of four divisions of the American Society for Engineering Education (ethics, community engagement, educational research \& methods, liberal education and engineering \& society), the authors of papers on ethics education in engineering/computing settings, advisors of EPICS, and NSF grantees on engineering ethics education. Invitations to the co-curricular survey were sent to email lists of student chapter advisors of engineering service groups (including Engineers Without Borders, Engineering 
World Health, and Bridges To Prosperity), engineering professional societies (such as the American Society of Civil Engineers, American Institute of Chemical Engineers, Society of Women Engineers, etc.), engineering honor societies (such as Tau Beta Pi), engineering design competitions, and the PIs of NSF-funded Research Experiences for Undergraduates (REU) sites in engineering. Additional details on individuals invited to participate in the survey have been published. ${ }^{38-40}$ Responses through May 22, 2016, were included in the analysis. Incomplete responses were closed and included with the data. Table 2 summarizes the demographics of the 212 respondents who described their senior capstone design course in question 3 or 8 , the 486 instructors who reported teaching ethical issues in senior capstone design in question 2 , and respondents who don't teach capstone (based on their response to question 2).

Table 2. Demographics of Survey Respondents

\begin{tabular}{|c|c|c|c|c|}
\hline Respondent Characteristics & $\begin{array}{c}\text { Described Sr } \\
\text { Design } \\
\text { Course } \\
(\mathrm{n}=212)\end{array}$ & $\begin{array}{l}\text { Sr Design } \\
\text { Course } \\
\text { Instructors } \\
(n=486)\end{array}$ & $\begin{array}{l}\text { Other Non- } \\
\text { Capstone } \\
\text { Respondents } \\
(\mathrm{n}=741)\end{array}$ & $\begin{array}{c}\text { National } \\
\text { ASEE } \\
\text { Statistics }^{41}\end{array}$ \\
\hline Institutions & $(n=152)$ & $(n=257)$ & $(n=344)$ & \\
\hline Public, $\%$ & 67 & 69 & 75 & \\
\hline Private, $\%$ & 33 & 31 & 25 & \\
\hline Doctoral, \% & 76 & 75 & 82 & \\
\hline Master's, \% & 16 & 16 & 12 & \\
\hline Bachelor's, \% & 8 & 9 & 5 & \\
\hline Disciplines taught (can be multiple) & & & & $\dagger$ \\
\hline Civil engineering & 24 & 25 & 22 & $12^{\wedge}$ \\
\hline Mechanical engineering & 22 & 23 & 20 & 17 \\
\hline Computer science/engineering & 13 & 14 & 18 & 13 \\
\hline Electrical engineering & 17 & 16 & 11 & 21 \\
\hline Chemical engineering & 14 & 11 & 11 & 7 \\
\hline Environmental engineering & 10 & 12 & 13 & $4^{\wedge}$ \\
\hline Biomedical & 9 & 10 & 9 & 6 \\
\hline Others (ind, aero, matls, mining, etc.) & 9 & 12 & 17 & 23 \\
\hline Ranks & & & & \\
\hline Full professor, \% & 36 & 37 & 32 & 40 \\
\hline Associate professor, $\%$ & 31 & 31 & 27 & 23 \\
\hline Assistant professor, \% & 16 & 16 & 19 & 19 \\
\hline Instructors, \% & 11 & 11 & 13 & 12 \\
\hline Other: part time, adjunct, staff; $\%$ & 6 & 5 & 9 & $7^{+}$ \\
\hline Other institutional roles & & & & \\
\hline ABET assessment coordinator & 17 & 14 & 7 & \\
\hline Director of program or center & 15 & 17 & 15 & \\
\hline Department head or chair & 9 & 12 & 7 & \\
\hline Other roles: assoc chair, etc. & 20 & 20 & 18 & \\
\hline $\begin{array}{l}\text { Professional Engineering License (P.E. } \\
\text { or similar), yes, } \%\end{array}$ & 41 & 38 & 26 & \\
\hline Male, $\%$ & 71 & 71 & 61 & -- \\
\hline Female, $\%$ & 26 & 26 & 36 & $15.7^{\dagger}$ \\
\hline Prefer not to say, $\%$ & 3 & 3 & 3 & \\
\hline
\end{tabular}

$\dagger$ Tenured/tenure-track; ${ }^{+}$full-time equivalent of all part-time personnel;

"ASEE reports a category of civil/environmental; this was counted with both "civil" and "environmental" 
The capstone design instructors represented many different institutions and institutional types, and taught students from a wide variety of engineering disciplines. The survey respondents overall were somewhat over-represented in civil/environmental engineering instructors. The "other" disciplines taught represents individuals who did not teach one of the major engineering disciplines shown but rather one or more other disciplines including: industrial, aerospace, materials, engineering technology, mining, petroleum, agricultural, nuclear, architectural, engineering management, and plastics. The capstone instructors themselves represented a range of ranks and many held additional roles at their institution. For example, the instructors of capstone design courses were more likely to also serve as the ABET assessment coordinator for their program than the non-capstone survey respondents. The capstone design instructors were more likely to hold professional engineering licenses versus non-capstone survey respondents. Females were over-represented among survey respondents, with a greater representation among the non-capstone instructors.

To determine if there were differences among disciplines or between capstone design instructors and non-capstone design instructors, statistical tests were conducted in Excel or IBM SPSS version 23. Chi-squared tests are useful to examine differences between categorical data, unlike the t-test which is often used with continuous data. Thus, chi-squared tests were used determine if an outcome (e.g. such as whether or not instructors teach sustainability in capstone design) was independent of the discipline (e.g. such that a similar percentage of civil, electrical, and mechanical engineering instructors teach sustainability in capstone design). To compare counts, such as total number of ESI topics taught among disciplines, non-parametric Mann-Whitney tests (to compare two groups) or Kruskal-Wallis tests (to compare multiple groups) were conducted; non-parametric tests do not require that the data is normally distributed, unlike t-tests. Significant differences were inferred when the significance level in the test was 0.05 or lower.

At the end of the surveys, respondents were invited to provide their email address if they were interested in being contacted for a follow-up interview. The interview phase of the study was designed to gain a deeper understanding of exemplary teaching practices and gain insight into educators' perceptions of their efficacy; this phase of the study is still in-progress. Interview selection was based on willingness to participate and representation of a range of pedagogical approaches in different disciplinary, academic, and institutional settings. Of the over 1400 total responses that were collected from the surveys, 229 respondents volunteered to be interviewed. Between October 2016 and February 2017, 53 individuals were invited to participate in the interviews. The individuals invited for interviews were $36 \%$ female, $62 \%$ worked at public institutions, and $18 \%$ are affiliated with departments outside of engineering. The educators were invited via email and were sent a follow-up email if no response was received. As of March 18, 2017, 34 interviews have been completed, and 4 more individuals agreed to participate but the interview has not yet been completed. The semi-structured interviews were conducted via Skype or phone and were 30-60 minutes in duration. Prior to the interview, participants were emailed a consent form for review and verbal consent was collected at the start of the interview. The interviews were recorded via Callnote. After the interviews, 2-page summaries were written and emailed to the interviewee for a member check to increase the accuracy and validity of the qualitative research. ${ }^{42}$ The audio files were used to generate verbatim transcripts using Dragon Speak. Pseudonyms were assigned to the interviewees using a random name generator to protect the anonymity and confidentiality of the participants. ${ }^{43}$ Thematic analysis of the interviews is on- 
going, but examples from three interviews with capstone design instructors are included in this manuscript to provide richness to the results.

\section{Results and Discussion}

\section{RQ1. Ethical and Societal Impact Topics}

The survey asked individuals if they taught any of a range of ethics-related topics in any of their courses, followed by the types of courses where these topics were taught. Only 61 survey respondents reported senior capstone design ( $\mathrm{Sr}$ design) as the only course type where they taught ethics related topics. An average of 5.6 ethics-related topics were reported in capstone design courses by these individuals. The most common ethics-related topics were: professional practice issues, safety, engineering code of ethics, engineering decisions under uncertainty, societal impacts of technology, and risk and liability (Table 3). The 57\% who included safety issues and $48 \%$ who included the societal impacts of technology in capstone design courses found in this study is similar to the $64 \%$ and $46 \%$ of chemical engineering capstone instructors who included safety and societal impact, respectively. ${ }^{34}$ The $30 \%$ inclusion of sustainability in this study is lower than the $53 \%$ reported previously by Howe et al. ${ }^{32}$ but higher than the $23 \%$ found in chemical engineering capstone $\operatorname{courses}^{34}$; differences may be due to the mix of disciplines among survey respondents.

Table 3. Percentage of instructors reporting teaching the topic in one or more courses

\begin{tabular}{|lccc|}
\hline Ethics-related topics & $\begin{array}{c}\text { Only Sr } \\
\text { Design Course } \\
(\mathrm{n}=61)\end{array}$ & $\begin{array}{c}\text { Sr Design and } \\
\text { Others } \\
(\mathrm{n}=486)\end{array}$ & $\begin{array}{c}\text { Non Sr Design } \\
\text { Courses } \\
(\mathrm{n}=739)\end{array}$ \\
\hline Professional Practice Issues & 61 & 72 & 55 \\
Safety & $57^{*}$ & 64 & 40 \\
Engineering Code of Ethics & $56^{*}$ & 58 & 40 \\
Engineering decisions under uncertainty & 51 & 59 & 46 \\
Societal impacts of technology & 48 & 62 & 53 \\
Risk and liability & $48^{*}$ & 48 & 30 \\
Ethics in design & $44^{*}$ & 59 & 29 \\
Ethical failures / disasters & 39 & 55 & 39 \\
Sustainability / Sustainable Development & 30 & 53 & 43 \\
Responsible conduct of research & 30 & 36 & 33 \\
Environmental protection issues & 28 & 42 & 32 \\
Ethical theories & 18 & 25 & 23 \\
Privacy and civil liberties & 12 & 14 & 14 \\
Social justice & $7 *$ & 16 & 21 \\
Engineering and poverty & 7 & 17 & 16 \\
Bioethics & 7 & 8 & 8 \\
Other & $3 *$ & 5 & 13 \\
War, peace, military applications of engrg & $2 *$ & 9 & 10 \\
Nanotechnology & 2 & 5 & 4 \\
\hline Average number of course types with ethics & 1 & 3.1 & 1.7 \\
\hline Average number of ethics topics & 5.6 & 7.2 & 5.6 \\
\hline
\end{tabular}

* chi-square test sig. $<0.05$ for only Sr Design vs. Non SR Design 
Among the entire group of 486 individuals who taught ethics-related topics in capstone design only and in addition other course types (an average of three course types), additional prevalent topics were: ethics in design, ethical failures/disasters, and sustainability. The inclusion of sustainability by this much larger group at $53 \%$ matches that found in the capstone study by Howe et al. ${ }^{32}$ Given that these responses represent multiple course types, the higher average number of ethics-related topics taught by these individuals (7.2) compared to the capstone only group (5.6) is not surprising. Other ESI topics written in were:
- teamwork
- universal usability
- ethical leadership
- respect for autonomy
- diversity
- resilience
- aboriginal concerns
- life cycle design
- intellectual property
- HIPPA
- globalization

- humanitarian application of engineering

- design research and human subjects

- values-based decision-making

- engineering licensure

- survey on student ethical beliefs

Comparing the topics taught in capstone design courses to the topics taught by non-capstone design instructors in other course types, capstone design courses more frequently included: risk and liability, ethics in design, safety, and engineering codes of ethics. In contrast, capstone design courses were less likely to include social justice and war, peace, military applications of engineering. This indicates that different course types appear to lend themselves more readily to particular ethics-related topics.

There were 212 individuals who described their capstone design course in detail later in the survey. Three disciplines predominated among those respondents: civil engineering $(n=51)$, mechanical engineering $(n=47)$, and electrical engineering $(n=37)$. Significant differences were found in the frequency that some ethical topics were taught among individuals in different disciplines, as summarized in Table 4. Overall, civil engineering capstone design instructors reported a higher number of ethics topics as compared to peers in electrical or mechanical engineering. This may indicate a greater overall focus on ethics in civil engineering capstone design courses.

Table 4. Percentage of senior capstone design instructors who teach different ethics topics

\begin{tabular}{|lcccc|}
\hline Ethics-Related Topic & Civil & Mechanical & Electrical & Chi test p value \\
\hline Sustainability & 78 & 43 & 35 & $<0.0001$ \\
Ethical failures/disaster & 73 & 51 & 41 & 0.01 \\
Professional practice issues & 90 & 64 & 60 & 0.0003 \\
Environmental protection issues & 59 & 34 & 30 & 0.009 \\
Engineering code of ethics & 78 & 62 & 70 & 0.04 \\
\hline Average number of ethics topics & 8.3 & 4.1 & 4.5 & \\
\hline
\end{tabular}

It is interesting to note that only $31 \%$ of the respondents selected their capstone design course as the one course in which they believed they most effectively taught engineering and/or computing students about ethical and/or societal impact issues (among the 390 individuals who taught ethical issues in capstone design and other courses, and went on in the survey to describe a most effective course). Thus, although ethical issues are included in their capstone design courses, many of the instructors believe that they teach students more effectively about these issues in 
another course. The other course types described as "most effective" by the capstone design instructors were most commonly engineering science/engineering courses at the sophomore to junior level $(22 \%)$ or design courses in the sophomore-senior year (non-capstone; $21 \%$ ); with graduate courses $(14 \%)$, first-year introduction courses $(14 \%)$, professional issues courses (12\%), first-year design (6\%), full ethics courses (4\%), and humanities/social science courses (4\%) also represented. Overall, over half of the capstone design instructors (58\%) did select a design-focused course as the course type where they most effectively taught ethical/social issues.

RQ2. Teaching Methods

The methods used to teach ethics in capstone design courses are summarized in Table 5. Among the 212 capstone courses described, $95 \%$ were required for students in one or more majors and $6 \%$ were electives for students in one or more majors ( 3 of the courses were listed as both). An average of 4.9 different methods were used in a capstone course to teach ethics, ranging from 1 to 15 . This is higher than the average of 1.2 pedagogies used to teach ethics in capstone design that were identified by students ${ }^{33}$; the difference may be due to the inclusion of macroethical / societal impact issues in the current study whereas students may have defined ethics more narrowly. The most commonly used methods to teach ethical issues were: engineering design, case studies, in-class discussion, examples of professional scenarios, lectures, and project based learning (PBL). Some differences were found between disciplines; for example, professional scenarios were more commonly used in civil engineering but PBL was less common compared to mechanical engineering.

Table 5. Percentage of senior capstone design courses where ethics was taught using a particular type of teaching method

\begin{tabular}{|lccc|}
\hline $\begin{array}{l}\text { Types of methods used to teach ethics/societal impact } \\
\text { issues }\end{array}$ & $\begin{array}{c}\text { Sr Design } \\
\text { Courses } \\
(\mathrm{n}=212)\end{array}$ & $\begin{array}{c}\text { Civil Sr } \\
\text { Design } \\
(\mathrm{n}=51)\end{array}$ & $\begin{array}{c}\text { Mech Sr } \\
\text { Design } \\
(\mathrm{n}=47)\end{array}$ \\
\hline Engineering design & 70 & 71 & 70 \\
Case studies & 58 & 61 & 51 \\
In-class discussions & 58 & 65 & 47 \\
Examples professional scenarios & 57 & $67 *$ & 45 \\
Lectures & 55 & 53 & 53 \\
Project based learning (PBL) & 53 & $41 *$ & 62 \\
Guest lectures (e.g., philosophers, social scientists) & 37 & 41 & 32 \\
Videos, movie clips & 19 & 18 & 19 \\
Reflections & 17 & 14 & 23 \\
Problem solving heuristics & 17 & 14 & 17 \\
Service-learning, community engagement, and/or LTS & 14 & 12 & 17 \\
In-class debates and/or role plays & 13 & 18 & 13 \\
Think-pair-share & 8 & 2 & 9 \\
Other(s) [fill in] & 7 & 6 & 9 \\
Moral exemplars & 6 & 14 & 4 \\
Humanist readings & 2 & 0 & 2 \\
\hline Average number pedagogies & 4.9 & 4.9 & 4.7 \\
\hline
\end{tabular}

$* \mathrm{p}<0.05$ in chi-square test compared to mechanical engineering 
Other teaching methods in capstone design courses that were written-in included: written report on study topic; failure modes and effects analysis; risk analysis; an online module based on their textbook (Engineering Design by Dym and Little ${ }^{44}$ ); online ethics module; online courses; CITI training for research with human subjects; students are required to attend a public hearing on an engineering project; safety analysis assignment; narratives of former projects and ethics outcomes. Some comments elaborated on the choices already provided: NSPE ethics videos; social service projects; students analyze ethical issues and case studies, articles, etc. and moderate class discussion.

The results indicate that ethics and societal impacts can be highlighted as issues within capstone design projects, and also taught via additional methods. The use of a variety of methods may be an effective way to embrace multiple domains of student learning and is in line with Vanasupa's ${ }^{31}$ 4DDD model. Student-centered and active teaching methods appear common (e.g. design, in-class discussions, PBL, reflections). Some methods are more likely to target the cognitive domain (such as lectures, problem solving heuristics), while others are more likely to target the affective domain (reflections, service-learning). Social interaction is present in class discussions, debates, and think-pair-share. The psychomotor is perhaps the most challenging domain to integrate, but could be present in service-learning or engineering design via such methods as hands-on project construction. If the students are able to understand the ethical issues at the core of their design project, this authentic context may help to drive their motivation cycle for learning; the extent to which students can exercise autonomy and choice in the experience may also enhance their motivation and learning.

The use of a combination of teaching methods may also relate to targeting different ethical topics or issues via different methods. In an analysis of cross-counting topics and teaching method convergence among the 61 individuals who only taught ethics in capstone courses, differences were found in the teaching methods that corresponded to topics. For example, lectures were the most prevalent teaching method only for the ethical topics of engineering codes of ethics and risk/liability. Case studies were the most common teaching method for societal impacts of technology, ethical failures, and responsible conduct of research. Engineering design was the most common teaching method for safety, engineering decisions under uncertainty, professional practice issues, ethics in design, environmental impacts, and sustainability. Professional scenarios were most commonly aligned with ethical theories. Discussion was most commonly aligned with social justice. Thus, some topics appear to lend themselves to instruction in senior capstone design via different methods.

The multiplicity of ethical teaching methods may also be related to the level of ethical development being targeted, across facets such as ethics knowledge, ethical reasoning, and ethical behavior (per the definition of Finelli et al. ${ }^{33}$ ). Alternatively, different teaching styles align with different student learning preferences (visual = videos; auditory = guest lectures, lectures, discussions, debates; reading/writing = case studies, humanist readings). Further research would be needed to probe the reasons that faculty chose to design the ethics instruction in their capstone courses in particular ways. 
The interviews helped illuminate how teaching methods align with instruction of broader impacts in the context of capstone design. An interviewee who teaches environmental engineering capstone design, which is four credits over two quarters, integrates a range of pedagogical approaches to "probe deeply into [ethical] issues" and "fill in gaps" of skills that are not explicitly technical but necessary for careers in engineering. As she explained, case studies afford the opportunity to connect the material to professional practice and situations that might be encountered in industry, guided discussions help students make parallels to their personal experiences, and role-playing activities allow the students to consider multiple perspectives and how different stakeholders impact decision-making. The interviewee uses the combination of teaching methods to "make sure students understand they are doing engineering in a social context." Another interviewee who teaches a two-semester, six credit capstone design sequence in electrical and computer engineering noted that a variety of teaching methods in the context of projects allow him to integrate ethics "organically and holistically because what we found is every time we try to teach ethics it is seen as an add-on, a bolt-on to the program, it's outside the purview of what engineering should be." Embedding ethics in the framework of design representations and client interviews encourages the students to look beyond Kant's deontological (duty or rule-based) ethics and address ESI from the challenges they face on their projects. The instructor also assigns students to write letters at the end of the year to the incoming cohort. This exercise is reflective for the graduating students and valuable for the incoming students. The letters are effective because the incoming students get insight into the social, professional, and ethical issues encountered in the design projects and hear from their peers that the greatest challenges are often not the technical ones. An interviewee who teaches a capstone design sequence in paper and chemical engineering, which is five credits over two semesters, echoed the importance of incorporating ESI into multiple instances in the design process. She commented that ethics instruction is a "more effective educational process if you have it show up frequently in various contexts" otherwise it is treated as "another hoop the student jumps through and doesn't worry about again." Designing pedagogy to infuse ESI into students' capstone design experiences can effectively demonstrate the intrinsic link between engineering and ethics.

\section{RQ3. Assessment Methods}

The capstone course instructors reported the type of assessment methods that were used to evaluate the outcomes of instruction on ethical issues (Table 6). An average of 2.0 different methods were used, with a range of 0 to 8 methods. The most commonly used assessment method was a group-based written assignment. Based on the write-in comments, this was likely one of the normal design deliverables from the student team; the deliverable was assessed for evidence of the inclusion of ethical considerations in the design process. This type of assignment might activate a social context for learning, assuming that the students work together on the ethics-related portions of the project. Other commonly used methods were individual reflective essays or individual homework assignments that were graded with a rubric. In all, 55\% of the capstone courses included one or more of the individual assessment methods; this is higher than reported by Howe et al. ${ }^{32}$ where $30 \%$ of the capstone courses used individual assignments to assess ethics, and $13 \%$ used individual assignments to assess sustainability. Given the difficulty of determining individual ethics knowledge, attitudes, and/or behavior from a team-based 
assessment, pairing assessment from a team-based deliverable and an individual assessment method (homework, reflection, and/or test questions) would be recommended as a best practice.

Table 6. Percentage of courses that use different assessment methods for outcomes of ethics / societal impacts instruction

\begin{tabular}{|lcc|}
\hline Types of methods used to assess ethics/societal impact issues & $\begin{array}{c}\text { Sr Design } \\
\text { courses } \\
(\mathrm{n}=212)\end{array}$ & $\begin{array}{c}\text { Sr Design } \\
\text { course with } \\
\text { SL/LTS } \\
(\mathrm{n}=31)\end{array}$ \\
\hline Group-based written assignment & 47 & 52 \\
Individual reflective essays & 33 & $55^{*}$ \\
Individual homework assignment, essay, and/or papers that are & 31 & 39 \\
$\quad$ graded with a rubric & 28 & 39 \\
Team ratings & 23 & 19 \\
Test and/or quiz questions & 14 & 23 \\
Other (describe) & 13 & 16 \\
Surveys & 10 & 3 \\
Individual homework assignments where questions have fairly & & \\
$\quad$ straight forward right and wrong answers (similar to & & \\
$\quad$ Fundamentals of Engineering type questions) & 10 & 3 \\
Do not assess these learning outcomes & 1 & 3 \\
Individual standardized assessment method (e.g. DIT, EERI, ESIT) & 2.0 & 2.6 \\
\hline Average number assessment methods & & \\
\hline
\end{tabular}

* chi-square test sig. $<0.05$ compared to non SL capstone courses

Ten percent of the courses indicated that ethics learning outcomes were not assessed. Disciplinary differences in ethics assessment methods were not found (data not shown). Assessment methods did not vary significantly in alignment with different teaching methods (data not shown), with the exception of greater use of reflective essays for ethics assessment in courses that included service-learning (SL) or other service elements; this is not surprising, given that reflection is encouraged as a required element in all SL courses. ${ }^{45-46}$

Group-based written assignments were found to be the most common assessment method that aligned with 15 of the ethical/societal impact topics (in the capstone-only courses). There were three exceptions. Individual homework assignments graded with a rubric was the most common assessment method that aligned with engineering decisions under uncertainty and environmental protection issues. Reflection was the most common assessment method aligned with ethical theories. The results indicate that with the proper rubrics and guidance to students on expectations, the core design project deliverables can be used to assess ethics-related outcomes.

Other assessment methods for ethics instruction that were written in by the capstone design instructors included:

- student oral presentations $(8 \mathrm{x})$

- rubric-graded discussion sessions $(3 \mathrm{x})$

- performance appraisal interviews

- student-led discussions

- oral progress reports

- judge feedback at annual end-of-the-year design expo 
Some of the write-in comments appeared to elaborate on choices that were provided:

- team based engineering projects in which students need to identify the ethical, societal, environmental and legal issues related to their projects

- written reports that are evaluated by practicing professional engineers

- design critiques
- group deliverables, assessment of the use of process, risk analysis and problem tracking, safety considerations

- final design report includes a failure modes and effects analysis section

- rubrics for technical reports

The capstone design instructors rated their level of satisfaction with their ability to assess the outcomes of societal context and ethics instruction in their course, using a Likert-type scale from 1 (very dissatisfied) to 7 (very satisfied). The majority (62\%) were satisfied, with $23 \%$ neutral and $15 \%$ dissatisfied. There is some indication that instructors may be more satisfied with some types of assessment methods than others. The highest average satisfaction was found among the three instructors who used a standardized individual assessment method (avg. 5.3), followed closely by those who used test and/or quiz questions ( $n=48$; avg. 5.2), and team ratings $(n=60$; avg. 5.1). The lowest satisfaction was found for those using individual homework assignments where questions have fairly straight forward right and wrong answers (similar to FE type questions) (n=21; avg. 4.6).

Instructor satisfaction with the ability to assess the outcomes of societal context and ethics instruction in capstone design courses appeared to increase with the number of assessment methods employed; Table 7. The Spearman's rho from the correlation of satisfaction with number of assessment methods was 0.254, with a 2-tailed significance of 0.000. Despite this, the most common response (mode) was a single ethics assessment method. However, this data suggests that use of three or more assessment methods will increase satisfaction with assessing the outcomes from ethics instruction.

Table 7. Number of assessment methods used for ethics learning evaluation and different average satisfaction levels

\begin{tabular}{|ccc|}
\hline $\begin{array}{c}\text { \# assessment } \\
\text { methods used }\end{array}$ & $\begin{array}{c}\text { Number of } \\
\text { courses }\end{array}$ & $\begin{array}{c}\text { Average Satisfaction with Ethics } \\
\text { Education Assessment }\end{array}$ \\
\hline 0 & 22 & 3.95 \\
1 & 68 & 4.70 \\
2 & 60 & 4.78 \\
3 & 28 & 4.96 \\
4 & 13 & 5.15 \\
$5-8$ & 17 & 5.35 \\
\hline
\end{tabular}

RQ4. Perceptions of Ethics Instruction in Capstone Design Courses

Faculty were asked where they believed that undergraduate students in their program learned about the societal impacts of technology and/or ethics. Among all 1189 respondents who answered this question, senior capstone design was the most commonly identified course type among nine options (62\%). Among the 745 respondents who did not teach capstone design and did indicate where they believed students learned these topics, the majority, 52\% indicated capstone design among the courses and/or co-curricular activities; this compares to $79 \%$ of the 
444 capstone design instructors who answered this question (strangely less than $100 \%$, despite their own indication that they taught ethical/social issues in capstone design). Thus, a number of engineering faculty are perhaps unaware that instruction on societal impacts and ethical issues occurs in the majority of capstone design courses. The perception that students learn about ethics and societal impact issues in capstone design courses did not vary significantly between disciplines (53\% civil, 57\% mechanical, $48 \%$ electrical; chi-test p-value 0.40 ). Drawing from the interview with faculty after the survey, one environmental engineering senior design instructor commented that since ethics and broader impacts are part of ABET, it is expected that programs address these considerations and that senior design is the most appropriate place for that instruction since students are exposed to the environmental, economic, and ethical implications of real design challenges. This agrees with the results from the chemical engineering capstone design survey, where the majority of capstone courses that included ethics and societal impacts were also used to assess those outcomes for ABET. ${ }^{34}$

\section{Open Response Comments}

Near the end of the survey, respondents were invited to share their general thoughts about the education of engineering students regarding broader impacts and ethical issues. These comments were explored and coded for themes that fell into four general areas: current practices, topics, challenges, and goals/opportunities. ${ }^{47}$ About six comments were specific to senior capstone design. Four of the comments indicated that the respondent thought that ethical issues were very important, but given little coverage in the curriculum other than senior design. And some still had concerns that ethics education in senior design was uneven.

"I think that both broader impacts and ethical issues are crucial but ignored in most places. They are great tools for motivation of engineering study and should be folded into nearly every class that is given to the students. In addition, as many students as possible should be doing projects that help them to understand these implications, either in class or through student groups. At my university, I believe this happens in the most depth in student groups and possibly then in senior design/capstone."

"I think it's important. ... I don't believe there are many places that students really get exposure to these topics in depth. They may 'come up' in other courses but often it's not until capstone design that students really have to wrestle with these issues (and sometimes not even then)."

"I think our undergrads are getting (barely) enough info on ethics through case studies and guest lectures during freshman seminar and senior capstone design courses, although more exposure would be better. They really don't get much about broader impacts unless they happen to be involved in an extra-curricular activity like EWB."

Two comments mentioned ABET, for example: "Technological impacts and exposure to ethics are ABET requirements that need to be covered. So assignments are included in our senior capstone sequence. Students write a reflective paper on impacts. For ethics, they are given a survey which contains 10 scenarios to see what they would do." One comment noted the differences among majors at their institution that were apparent in the multi-disciplinary senior 
design course; whereas biomedical engineering students in their program were required to take a 3-credit senior-level course on bioethics, the "[ME and EE] students have little or no exposure to societal and ethical issues in engineering."

One capstone instructor also shared a general comment in the write-in space for teaching methods: "I think the emphasis on this topic is overblown; changes each year, not sure what we'll do this year." Although most of the respondents spoke of the importance of ethics instruction and the opportunities for improvement, this comment reflects a minority sub-set of educators who commented that there is too much focus on ethical issues.

The comments reflect specifics at institutions, as well as perceived disciplinary differences. The written responses illuminate the current practices for teaching ethical issues and broader impacts in senior capstone design as well as barriers and opportunities for increasing student learning. The comments also bring up issues of depth versus breadth, and the specific learning outcomes targeted - ethical behavior? ethical reasoning?

\section{Limitations}

One of the limitations of the research includes the fact that capstone design instructors were not directly solicited for their input. Thus, one can imagine that individuals who teach ethics and societal impact issues in their capstone course may have been more likely to participate in the survey, compared to individuals who teach capstone design and do not infuse ethical and societal issues. However, Howe's previous survey on capstone courses found that only $12 \%$ indicated that they did not teach ethics in their course ${ }^{32}$; our results appear similar in that respect. A second limitation is the fact that, because of the way the survey was designed, we could only directly see which topics were covered in capstone design if that was the only course where the respondent taught ethical/societal issues $(\mathrm{n}=61)$. A number of other respondents reported teaching ethical issues in a number of courses, preventing attribution of the topics specifically to capstone design in those cases.

Because the number of respondents from individual disciplines were limited, future work could expand to a critical mass of respondents from a larger number of disciplines. In this research only three disciplines were routinely compared: civil, mechanical, and electrical. The interview research that is in-progress may also have additional individuals who discuss their instruction of ethical/social issues in senior capstone design.

\section{Conclusions}

This research provides capstone design instructors with ideas for infusing ethics and societal impact issues into their courses, and assessing the outcomes of that instruction. A broader range of ESI topics was explored in this study compared to previous research, enabling a more detailed understanding of the types of ethical topics that are covered as well as including macroethical issues. A wide variety of ethics and societal impact topics have been infused in capstone design courses - one or more capstone courses included the 18 ESI topics included on the survey, and another 17 topics were written in. Some topics are appropriate for any capstone design course (professional issues; safety; ethics in design; engineering decisions in the face of uncertainty; 
impacts on society), while others may be a better fit for courses in particular disciplines or depending on the project types (responsible conduct of research, bioethics, war/peace/military applications of engineering, engineering and poverty). The topic list may inspire capstone instructors to enrich the range of ESI topics included in their courses. One exemplar course, a single semester, 3-credit civil engineering capstone course, included 12 ESI topics.

Most courses used multiple methods to teach ESI, an average of 5. An effective teaching approach includes ethical issues within the core project and project deliverables, as well as supporting student-centered and/or active learning methods such as in-class discussions. Instructors should consider how their pedagogy encompasses the four domains in the 4DDD model $^{31}$ : cognitive, affective, social, and psychomotor. A wide variety of methods have been used to assess ethics learning outcomes, with three or more methods providing the highest level of satisfaction to instructors. Assessment methods associated with ESI in the context of capstone design have been poorly reported in the past. Assessing the core project deliverables (presumably team based) with a rubric and an individual assignment is recommended as a best practice. The assessment data could be used to contribute to ABET evaluation processes for both the ethics and societal impacts outcomes.

Capstone instructors may want to work with colleagues to integrate the ESI instruction in capstone design with other curricular components. It appears that some individuals may be unaware that undergraduate students in their program are learning about ESI in capstone design. Capstone design instructors may also want to advocate for other faculty to include ESI issues in their courses; some of these topics can be readily infused into any course. This earlier exposure to ESI in the curriculum would likely benefit capstone design instructors, who can then build on that knowledge to help students achieve deeper levels of ethical reasoning.

\section{Acknowledgements}

This material is based on work supported by the National Science Foundation under Grant Nos. 1540348, 1540341, and 1540308. Any opinions, findings, and conclusions or recommendations expressed in this material are those of the author(s) and do not necessarily reflect the views of the National Science Foundation.

\section{References}

1. Wulf, Wm. A. 2002. Engineering Ethics (Editorial). The Bridge, 32 (2), 3. https://www.nae.edu/File.aspx?id=7378 Accessed Feb. 3, 2017.

2. National Society of Professional Engineers (NSPE). 2007. NSPE Code of Ethics for Engineers. https://www.nae.edu/File.aspx?id=7378 Accessed Feb. 3, 2017.

3. American Society for Engineering Education (ASEE). ASEE Code of Ethics. https://www.asee.org/memberresources/resources/Code_of_Ethics.pdf Accessed Feb. 3, 2017.

4. American Society of Civil Engineers. 2006. ASCE Code of Ethics. http://www.asce.org/code-of-ethics/ Accessed Feb. 3, 2017.

5. American Society of Mechanical Engineers (ASME). 2012. Society Policy: Ethics. PS-15.7, 2/1/12. https://www.asme.org/getmedia/9EB36017-FA98-477E-8A73-77B04B36D410/P157_Ethics.aspx Accessed Feb. 32017.

6. IEEE. IEEE Code of Ethics. http://www.ieee.org/about/corporate/governance/p7-8.html Accessed Feb. 3, 2017. 
7. American Institute of Chemical Engineer (AIChE). 2015. AIChE Code of Ethics. https://www.aiche.org/about/code-ethics Accessed Feb. 3, 2017.

8. Association for Computing Machinery (ACM). 1992. ACM Code of Ethics and Professional Conduct. https://ethics.acm.org/code-of-ethics/ Accessed Feb. 3, 2017.

9. National Academy of Engineering (NAE). 2004. Emerging Technologies and Ethical Issues in Engineering. National Academies Press, Washington D.C.

10. Zandvoort, H., T. Borsen, M. Deneke, S.J. Bird. 2013. Editor's Overview: Perspectives on Teaching Social Responsibility to Students in Science and Engineering. Sci. Eng. Ethics, 19: 1413-1438.

11. ABET Engineering Accreditation Commission (EAC). 2016. Criteria for Accrediting Engineering Programs. Effective for Reviews During the 2017-2018 Accreditation Cycle. Oct. 29, 2016. ABET, Inc. Baltimore, MD.

12. ABET Computing Accreditation Commission (CAC). 2016. Criteria for Accrediting Computing Programs. Effective for Reviews During the 2017-2018 Accreditation Cycle. Oct. 29, 2016. ABET, Inc. Baltimore, MD.

13. Barry, B.E., J.R. Herkert. 2014.Chapter 33. Engineering Ethics. In: Cambridge Handbook of Engineering Education Research. Eds. A. Johri and B.M. Olds. P 673-692. Cambridge University Press, NY.

14. American Society of Civil Engineers (ASCE). 2015. Commentary on the ABET Program Criteria for Civil and Similarly Named Programs. Effective for the 2016-2017 Accreditation Cycle. ASCE, Reston VA. 49 pp.

15. Davis, M. 1999. Teaching Ethics Across the Curriculum. OEC International Conference on Ethics in Engineering and Computer Science. Accessed from Online Ethics Center, http://www.onlineethics.org/Resources/instructessays/curriculum.aspx Dec. 12, 2016.

16. Cruz, J., W. Frey, H. Sanchez, A. Curbelo. 2008. Developing Engineering Ethics Across the Curriculum Best Practices: The EAC Toolkit. American Society for Engineering Education Annual Conference \& Exposition. Paper AC 2008-2834. Pittsburgh PA, June 22, 10 pp.

17. Falcone, F.E., E.F. Glynn, M.E. Graham, M. Doorley. 2013. Engineering Ethics Survey for Faculty: An Assessment Tool. American Society for Engineering Education Annual Conference \& Exposition. Paper ID \#7537. Atlanta GA.

18. University of Missouri St. Louis (UMSL). (2015). Joint Undergraduate Engineering Program. Pre-Engineering Program. http://www.umsl.edu/divisions/engineering/Pre-Engineering/ Accessed March 4, 2015

19. University of Illinois Urbana-Champaign. (2014). ECE/PHIL 316: Ethics and Engineering. Course Homepage. http://publish.illinois.edu/ecephil316/ Accessed March 4, 2015.

20. Texas A\&M University. PHIL 482 Ethics and Engineering. http://m.tamu.edu/courses/CourseDetail/dpt_sbj_code/PHUM/course_code/482/semester/Fall+2014/m/0 Accessed March 4, 2015

21. Georgia Institute of Technology. (2011). PHIL 3109 Engineering Ethics. Dr. Michael Hoffmann. http://www.prism.gatech.edu/ mh327/PHIL-3109_syllabus.pdf Accessed March 4, 2015.

22. Mattei, N.J. (2005). Is covering ethics in an analysis class effective? American Society for Engineering Education Annual Conference \& Exposition. ASEE. Washington DC

23. Brown, J. and Pfile R. (2006). The development of a one credit ethics course for engineering technology. Paper AC 2006-2287. American Society for Engineering Education Annual Conference \& Exposition. ASEE. Washington DC

24. Leitch, K.R. and Dittfurth R.B. (2012). Online and in-seat ethics instruction: the view from both sides. Paper AC 2012-3386. American Society for Engineering Education Annual Conference \& Exposition Proceedings. ASEE, Washington DC.

25. Freyne, S. and Hale, M. (2009). A preliminary survey of engineering ethics courses nationwide. Paper AC 2009-970. American Society for Engineering Education Annual Conference \& Exposition Proceedings. ASEE, Washington DC.

26. Cornell University College of Engineering. (2010). ENGRG 1050. Bovay Program. http://bovay.ece.cornell.edu/ENGRG1050.html Accessed March 4, 2015

27. Penn State (2008). School of Engineering Design, Technology, and Professional Programs. Course Descriptions. http://www.sedtapp.psu.edu/firstyear/course_descriptions.php Accessed March 4, 2015.

28. Bielefeldt, A.R. 2011. Sustainability Ethics among First-Year Civil and Environmental Engineering Students. Paper AC 2011-1362. American Society for Engineering Education (ASEE) Annual Conference and Exposition Proceedings. ASEE, Washington DC.

29. Godfrey, D., Taylor T., Fleischmann C., Pickles D. (2008). Teaching engineering ethics in a multi-disciplinary environment. Paper AC 2008-916. American Society for Engineering Education Annual Conference and Exposition Proceedings, ASEE, Washington DC. 
30. El-Sayed, M.E., El-Sayed J.A., Cameron T.M. (2011). Implementation and assessment of a capstone course designed to achieve program learning objectives. Paper AC 2011-837. American Society for Engineering Education Annual Conference \& Exposition. ASEE. Washington DC.

31. Vanasupa, L., J. Stolk, R.J. Herter. 2009. The Four-Domain Development Diagram: A Guide for Holistic Design of Effective Learning Experiences for the Twenty-first Century Engineer. Journal of Engineering Education. 98 (1), 67-81.

32. Howe, S., L. Rosenbauer, S. Poulos. 2016. 2015 Capstone Design Survey Initial Results. Proceedings of the 2016 Capstone Design Conference. Columbus OH, June 6-8, 4 pp. http://www.capstoneconf.org/resources/2016\%20Proceedings/Papers/0028.pdf

33. Finelli, C.J., M.A. Holsapple, E. Ra, R.M. Bielby, B.A. Burt, D.D. Carpenter, T.S. Harding, J.A. Sutkus. 2012. An Assessment of Engineering Students' Curricular and Co-Curricular Experiences and Their Ethical Development. Journal of Engineering Education. 101 (3), 469-494.

34. Silverstein, D.L, L.G. Bullard, W.D. Seider, M.A. Vigeant. 2013. How We Teach: Capstone Design. American Society for Engineering Education (ASEE) Annual Conference and Exposition. Atlanta GA, June 23-26, 15 pp. https://peer.asee.org/19689

35. Quinn, M.J. 2006. On Teaching Computer Ethics within a Computer Science Department. Science and Engineering Ethics, 12, 335-343.

36. Dekker, D., S. Sundarrao, R. Dubey. 2008. Capstone Design Courses: Content Recognition. American Society for Engineering Education (ASEE) Annual Conference and Exposition. Pittsburgh PA, June 22-25, 9 pp. https://peer.asee.org/4140

37. Bowers, S., E.M. Maccarone, G.D. Ricco. 2016. On the Integration of Ethical, Legal, and Societal Issues into a Computer Science Senior Design Capstone Program. American Society for Engineering Education (ASEE) Annual Conference and Exposition. New Orleans LA, June 26-28, 14 pp. DOI 10.18260/p.25826. https://peer.asee.org/25826

38. Bielefeldt, A.R., N.E. Canney, C. Swan, D. Knight. 2016. Efficacy of Macroethics Education in Engineering. American Society for Engineering Education (ASEE) Annual Conference and Exposition. New Orleans, LA, June 26-28, 21 pp. DOI 10.18260/p.26919.

39. Bielefeldt, A.R., D. Knight, C. Swan, N. Canney. 2016. Macroethics Education in Engineering and Computing Courses. Rocky Mountain Section Conference of the American Society for Engineering Education, Proceedings, Cedar City, UT, Sept. 30 - Oct. 1, 154-166.

40. Knight, D.W., N.E. Canney, A.R. Bielefeldt, C. Swan. 2016. Macroethics instruction in co-curricular settings: The development and results of a national survey. IEEE Frontiers in Education (FIE) Conference Proceedings, Erie, PA, Oct. 12-15.

41. Yoder, BL. 2015. Engineering By the Numbers. ASEE. https://www.asee.org/papers-andpublications/publications/college-profiles/15EngineeringbytheNumbersPart1.pdf

42. Koelsch, L.E. 2013. Reconceptualizing the Member Check Interview. International Journal of Qualitative Methods, 12: 168-179.

43. Given, L.M., ed. 2008. The Sage encyclopedia of qualitative research methods. Sage Publications.

44. Dym, C.L, P. Little. 2008. Engineering Design: A Project Based Introduction. $3^{\text {rd }}$ Edition. Wiley.

45. Bringle, R.G., J.A. Hatcher. 1999. Reflection in Service Learning: Making Meaning of Experience. Educational HORIZONS, Spring, 179-185

46. Eyler, J. 2002. Reflection: Linking Service and Learning - Linking Students and Communities. Journal of Social Issues, 58 (3), 517-534.

47. Canney, N.E., M. Polmear, A.R. Bielefeldt, D. Knight, C. Swan, E. Simon. 2017. Challenges and Opportunities: Faculty views on the state of macroethical education in engineering. American Society for Engineering Education (ASEE) Annual Conference and Exposition, Columbus, OH, June 25-28. 